\section{Lead exposure and periodontitis in US adults}

\author{
Saraiva MCP, Taichman RS, Braun T, Nriagu J, Eklund SA, Burt BA. Lead \\ exposure and periodontitis in US adults. J Periodont Res 2007; 42: 45-52. \\ (C) 2006 The Authors. Journal compilation () 2006 Blackwell Munksgaard
}

Background and Objective: Lead is known to have significant effects on bone metabolism and the immune system. This study tested the hypothesis that lead exposure affects periodontitis in adults.

Material and Methods: This study used the data from the Third National Health and Nutrition Examination Survey (NHANES III, 1988-94). It analyzed data from 2500 men and 2399 women, 20-56 yr old, who received complete periodontal examination. Periodontitis was defined as the presence of $>20 \%$ of mesial sites with $\geq 4 \mathrm{~mm}$ of attachment loss. Lead exposure was grouped into three categories: $<3 ; 3-7$; and $>7 \mu \mathrm{g} / \mathrm{dL}$. Covariates were cotinine levels, poverty ratio, race/ ethnicity, education, bone mineral density, diabetes, calcium intake, dental visit, and menopause (for women). All analyses were performed separately for men and women and considering the effect design. Univariate, bivariate, and stratified analysis was followed by multivariable analysis by estimating prevalence ratios through poisson regression.

Results: After adjustment for confounders, the prevalence ratios, comparing those with a lead blood level of $>7 \mu \mathrm{g} / \mathrm{dL}$ to those with a lead blood level of $<3 \mu \mathrm{g} / \mathrm{dL}$ was $1.70(95 \%$ confidence interval $(\mathrm{CI}): 1.02,2.85)$ for men and $3.80(95 \% \mathrm{CI}$ : $1.66,8.73)$ for women.

Conclusion: The lead blood level was positively and statistically associated with periodontitis for both men and women. Considering the public health importance of periodontitis and lead exposure, further studies are necessary to confirm this association.
M. C. P. Saraiva', R. S. Taichman², T. Braun ${ }^{3}$, J. Nriagu ${ }^{4}$, S. A. Eklund ${ }^{5}$, B. A. Burt ${ }^{5}$

${ }^{1}$ Department of Paediatrics and Social Dentistry, School of Dentistry of Ribeirão Preto, University of São Paulo, SP, Brazil, ${ }^{2}$ Department of Periodontics and Oral Medicine, Prevention, Geriatrics, School of Dentistry, University of Michigan, Ann Arbor, MI, USA and Departments of ${ }^{3}$ Biostatistics, ${ }^{4}$ Environmental Health Science, and ${ }^{5}$ Epidemiology, School of Public Health, University of Michigan, Ann Arbor, MI, USA

Maria da Conceição P. Saraiva, Avenue Do Café s/n, CEP 14040-904, Ribeirão Preto, São Paulo, Brazil

Tel: + 551636023995

Fax: + 551636330999

e-mail: mdsaraiv@umich.edu

Key words: adults; lead exposure; oral health; periodontitis; toxicology

Accepted for publication May 7, 2006
Despite the decline of environmental and occupational lead contamination in the past few decades, sources of lead exposure are still found in some neighborhoods, especially in the more underprivileged areas $(1,2)$. Moreover, it has been accepted that there is no threshold for the deleterious health effects of lead $(3,4)$. These facts strengthen the importance of continued investigation into the effects of lead on human health.

In the past two decades, increasing evidence has been gained to support the fact that chronic lead exposure may affect bone metabolism $(5,6)$ and possibly the immune system $(7,8)$. This evidence makes lead a potential risk factor for periodontitis - a complex multifactorial disease that affects bone - which is initiated by an imbalance of the host defense system and the pathogenicity of microorganisms (9).

Lead affects bone metabolism by interfering with calcium metabolism, which directly affects bone cells and bone matrix synthesis (6). Physiological mechanisms that control calcium levels affect the absorption, retention, and distribution of lead in a similar manner. As calcium regulates many cell functions, such as the response to hormonal and electrical stimuli, the interference of calcium metabolism by lead might also affect such cellular functions $(6,10)$.

The direct effect of lead on osteoblasts includes the impairment of bone matrix synthesis, the process of initiation of mineralization, and the regulation of bone resorption (6). Impairment of bone matrix is mostly caused by interference with the collagen and noncollagen protein synthesis $(11,12)$. Lead also displaces calcium 
ions from synthesized osteocalcin, which in turn inhibits its binding to hydroxyapatite, disturbing bone formation $(13,14)$. In vitro, lead stimulates the proliferation of osteoclastlike cells from the bone marrow of rats, and also the production of prostaglandin E2 (15).

Clinical evidence of the deleterious effect of lead exposure on bone metabolism in humans is reduced child growth (16-18). Development of osteopenia and osteoporosis (6) has also been proposed, but the evidence from human studies is still debatable. Osteopenia has been reported in rats exposed to low levels of lead in a dosedependent interaction with calcium intake $(19,20)$.

The effect of lead on the immune system has been attributed mostly to downregulation of a cell-mediated immune response (21). In in vitro and animal studies, lead exposure has been associated with imbalances of T-helper cell (Th1/Th2) activity (22), decreases in interferon- $\gamma$, and increases in tumor necrosis factor (23) and interleukin-12 (24). The effects of lead in humans are still controversial, mostly because of lack of control of confounders and small sample sizes of the majority of the studies. Among the effects of lead exposure in humans are the decreased percentage of monocytes, an increase in the percentage of $\mathrm{CD} 4^{+}$ cells $(25,26)$, and impaired polymorphnuclear neutrophil functions $(27,28)$.

Several of the cellular and immunologic responses to chronic lead exposure have also been described for periodontitis (29-31). We propose that the direct effect of lead on bone matrix formation has the potential to interfere with the progression of periodontitis, because bone is constantly remodeling and periodontitis is a relatively slow progressive disease characterized by periods of activity and quiescence. A recent study demonstrated that lead might impair the bone-healing process (32). Similar immunologic alterations associated with lead exposure, such as impaired chemotaxis and phagocytosis of polymorphnuclear neutrophils (29), imbalance of Th1/Th2 cells (31), and an increase in prostaglandin E2 production
(9), have also been reported for periodontitis. In fact, the causal association between lead exposure and periodontitis has already been proposed $(33,34)$. However, these studies had some limitations, such as lack of control of confounders and inappropriate control groups. Recently, an analysis of the Third National Health Examination Survey (NHANES III) data (35), using blood lead levels as the outcome variable, proposed that periodontal bone loss would contribute to the delivery of lead into the bloodstream. It is possible that periodontal attachment and bone loss might contribute to increased lead blood levels; however, given the episodic nature of periodontitis, it seems hardly likely that the association found was solely the result of periodontal breakdown tissue. The association found in that study might, in part, be attributed to lack of control of some confounders, such as osteopenia/ osteoporosis (30), menopause (36), and calcium intake (37). Thus, the objective of this study was to assess the association between lead blood levels and periodontitis in the United States population, using data from a representative national sample.

\section{Material and methods}

\section{Data source and study population}

The data source for this study was the NHANES III, a cross-sectional survey of a complex, multistage, stratified clustered sample intended to be representative of the civilian noninstitutionalized US population older than 6 mo (38). Oral examinations were performed in a mobile examination center by six trained and calibrated examiners. Clinical evaluation of periodontal tissues was performed in two diagonally opposite quadrants - one superior and another inferior - chosen at random for each individual. Quadrants did not include third molars, and only two sites (mesial-buccal and buccal) per tooth were examined. Detailed information of examination procedures have been reported previously (39).

NHANES III had an original sample size of 39,695 individuals, of whom
33,994 were interviewed. This study included only individuals from 30 to $55 \mathrm{yr}$ old. Individuals over $55 \mathrm{yr}$ old were excluded to avoid inclusion of survivors who predominate in elderly samples, resulting in an artificial stabilization of average attachment loss (or prevalence of periodontitis) according to age in a population. The cut-off point of $55 \mathrm{yr}$ was based on the point of stabilization of average attachment loss (which ranged from 52 to $55 \mathrm{yr}$ old) using a median-smoothing curve plotted for all individuals and stratified by gender and race/ethnicity.

Only individual Whites, AfricanAmericans, and Mexican-Americans with a complete periodontal examination and information on lead blood levels were included in this study. Because of increased bone metabolism resulting in significant increase in lead blood levels, pregnant $(n=253)$ and breastfeeding $(n=81)$ women were excluded from this study. The analyses thus proceeded with a total of 2399 women and 2500 men.

\section{Outcome variables}

The case-definition of periodontitis was at least $10 \%$ of mesial sites with at least $4 \mathrm{~mm}$ of clinical attachment loss (40). Clinical attachment loss was calculated by subtracting the distance from the gingival margin to the cemento-enamel junction from pocket depth (41). Only the information on attachment loss from mesial sites was included, avoiding any influence of gingival recession from buccal sites, which may not represent periodontitis.

\section{Exposure variable}

Lead exposure was measured as the total lead blood level $(\mu \mathrm{g} / \mathrm{dL})$. The lead blood level was categorized into three levels: < $3 \mu \mathrm{g} / \mathrm{dL} ; \quad 3-7 \mu \mathrm{g} / \mathrm{dL} ; \quad$ and $>7 \mu \mathrm{g} / \mathrm{dL}$. For this population, $3 \mu \mathrm{g} / \mathrm{dL}$ represents the 50th percentile and $7 \mu \mathrm{g} /$ $\mathrm{dL}$ represents approximately the 90th percentile of the distribution of lead.

\section{Covariates}

The following factors were used as covariates in the regression analysis: 
age, gender, presence of diabetes, cotinine blood levels, education, economic level (poverty), dental caries, tooth loss, and race/ethnicity (whites, African-Americans and Mexican-Americans). Diabetes was defined from a question included in the personal interview: 'have you ever been told by a doctor you had diabetes?'. Women who reported to have had diabetes only during pregnancy were not considered as diabetic. Cotinine levels were used to define tobacco smoking as well as smoking status (current, former, and never smokers). Cotinine levels ( $\mathrm{ng} / \mathrm{ml})$ were categorized into five levels representing the 60th, 70th, 80th and 90th percentile, respectively: $<1.53,1.54$ 63.3, 63.4-202.39, 202.40-305.8, and $>305.9$. Education was defined in three levels as $<12,12$ and $>12$ yr of education. Poverty ratio (family income divided by the poverty threshold for the year in which the family was interviewed) was categorized into three levels: $\leq 1.301 ; 1.301-3.500$; and $>3.500$ (38). Serum calcium was categorized according to the median level.

Levels of bone mineral density (BMD) were calculated separately for men and women, based on the standard deviation of the distribution of bone mineral density for non-Hispanic whites from 20 to $29 \mathrm{yr}$ old (42). Very low levels of BMD (osteoporosis) refers to more than 2.5 standard deviations below the mean; low levels of BMD (osteopenia) refers to scores from 1 to 2.5 standard deviations below the mean; high levels refers to 1 standard deviation below the mean up to the mean; and very high levels refers to BMD scores above the mean. The number of teeth present in the mouth was also used as covariate in order to take tooth loss into consideration (41).

Age of the participant's house was included in the models in an attempt to control for factors associated with current exposure to lead in paint. Time of construction of the house was available from NHANES III in three categories: house built before 1946; house built between 1946 and 1973; and house built after 1973. Menopause status was defined as women not having periods in the past 12 mo (excluding those reporting to be pregnant or breastfeeding during the past $12 \mathrm{mo}$ ). Current pregnancy information that was used to exclude individuals was assessed by the question 'are you pregnant now?' with the confirmation of a pregnancy test.

\section{Statistical analysis}

The statistical analysis was performed separately for men and women. This was because women are submitted to hormonal influences on bone metabolism during menopause (43), pregnancies, and breastfeeding (44). All analyses took into consideration the sampling design by using the survey procedures on the STATA 8.0 statistical program. Prevalence ratio was used as measurement of association calculated through poisson regression (45). Univariate and bivariate analysis was performed followed by stratified analysis and modeling. Multivariate poisson regression models were built backwards, keeping known confounders in the model, even if they were not significant (alpha $=0.05$ ). As there was a significant drop in lead blood levels from the phase I to the phase II of NHANES III, a variable identifying the survey phase was forced into the model. Systematic bias from examiners was also handled by considering a variable specific to each examiner. Some covariates, such as menopause and osteoporosis, were forced into the model in an attempt to control the increased delivery of lead stored in bones. Also, age of residence was forced into the model in an attempt to control for recent exposure to lead. Plausible interactions of the second order were also tested $(p<0.10)$.

\section{Results}

The average attachment loss on mesial tooth sites for women and men were, respectively, $1.1 \mathrm{~mm}$ [standard error $(\mathrm{SE})=0.05] \quad$ and $\quad 0.93 \mathrm{~mm} \quad(\mathrm{SE}=$ 0.04). Among men, the prevalence of individuals with at least $10 \%$ of their mesial sites showing attachment loss of at least $4 \mathrm{~mm}$ was $12.3 \% \quad(\mathrm{SE}=1.0)$ and among women the prevalence was $7.2 \%(\mathrm{SE}=0.61)$.
Table 1 shows the bivariate analysis for lead blood levels among women and men. The unadjusted prevalence ratio for lead blood level was statistically associated with periodontitis for both men and women.

Table 2 shows the adjusted prevalence ratio (sequential analysis) as the confounders are added to the model. After adjustments for socio-economic factors, the lead blood level prevalence ratio showed the highest drop when cotinine levels were added to the model. After the addition of cotinine levels, only small changes were observed in the adjusted prevalence ratio for lead blood level, both for men and for women. We tested the interaction between smoking status and lead blood level and no significant interactions were found (Table 3). The interaction between cotinine levels and lead blood level was also studied, but no interaction for men was found. The very small number of women (cells containing only one individual) with moderate cotinine levels and high lead blood levels precluded from testing the interaction of cotinine and lead blood level among women. Independent of smoking status, the prevalence ratio for high lead blood levels is $>1$, even for never smokers to whom the prevalence for periodontitis is very small. Among nonsmoker women, only $1.21 \%(\mathrm{SE}=0.43)$ had a lead blood level of $>7 \mu \mathrm{g} / \mathrm{dL}$ and among men this proportion was $6.2 \%(\mathrm{SE}=1.4)$. Moreover, the trend analysis was significant for men $(p=0.0373)$ and for women $(p=0.0230)$. No significant interactions were observed between lead blood level and the other covariates evaluated (serum calcium, poverty, race/ethnicity, osteoporosis, and education).

\section{Discussion}

This study showed a significant positive association between lead and periodontitis for both men and women. The prevalence ratio, comparing those with a lead blood level of $>7 \mu \mathrm{g} / \mathrm{dL}$ to those with a lead blood level of $<3 \mu \mathrm{g} / \mathrm{dL}$, was lower for men (prevalence ratio $=1.73,95 \%$ confidence interval (CI: 1.02, 2.92) than for 
Table 1. Characteristics of 30-55-yr-old men $(\mathrm{n}=2500)$ and women $(\mathrm{n}=2399)$ of the US population [data were obtained from the Third National Health and Nutrition Examination Survey (NHANES III, 1988-94)]

\begin{tabular}{|c|c|c|c|c|c|c|c|c|c|c|}
\hline & \multicolumn{5}{|l|}{ Men } & \multicolumn{5}{|c|}{ Women } \\
\hline & $n^{*}$ & $\% \dagger$ & $\mathrm{SE} \ddagger$ & $P R-$ & $95 \% \mathrm{CI} \S$ & $n^{*}$ & $\%$ & $\mathrm{SE}$ & PR & $95 \% \mathrm{CI}$ \\
\hline \multicolumn{11}{|l|}{ Race/ethnicity } \\
\hline White & 873 & 10.1 & 1.3 & 1.00 & & 853 & 5.3 & 0.9 & 1.00 & \\
\hline African-American & 771 & 24.2 & 1.6 & 2.39 & $1.78,3.21$ & 811 & 12.4 & 1.3 & 2.34 & $1.59,3.45$ \\
\hline Mexican-American & 856 & 12.4 & 1.2 & 1.23 & $0.90,1.67$ & 735 & 7.8 & 1.1 & 1.47 & $0.95,2.26$ \\
\hline$p$-value & & & & $<0.0001$ & & & & & $<0.0001$ & \\
\hline \multicolumn{11}{|l|}{ Poverty ratio } \\
\hline$>3.500$ & 699 & 9.0 & 1.3 & 1.00 & & 536 & 1.9 & 0.7 & 1.00 & \\
\hline $1.301-3.500$ & 716 & 10.8 & 1.5 & 1.18 & $0.83,1.70$ & 677 & 6.6 & 1.2 & 3.57 & $1.61,7.93$ \\
\hline$<1.301$ & 904 & 19.8 & 1.8 & 2.16 & $1.61,2.91$ & 1000 & 13.3 & 1.8 & 7.21 & $3.41,15.27$ \\
\hline$p$-value & & & & $<0.0001$ & & & & & $<0.0001$ & \\
\hline \multicolumn{11}{|l|}{ Education (years) } \\
\hline$>12$ & 915 & 5.7 & 0.9 & 1.00 & & 818 & 2.3 & 0.7 & 1.00 & \\
\hline$=12$ & 769 & 15.3 & 1.8 & 2.67 & $1.81,3.94$ & 851 & 8.7 & 1.3 & 3.72 & $1.97,7.02$ \\
\hline$<12$ & 750 & 26.4 & 2.6 & 4.61 & $3.29,6.46$ & 686 & 15.0 & 2.3 & 6.43 & $3.37,12.26$ \\
\hline$p$-value & & & & $<0.0001$ & & & & & $<0.0001$ & \\
\hline \multicolumn{11}{|l|}{ Dental visit } \\
\hline Every year $/ 2 \mathrm{yr}$ & 1052 & 7.4 & 1.0 & 1.00 & & 1263 & 2.7 & 0.6 & 1.00 & \\
\hline Whenever need/never & 1333 & 18.1 & 1.6 & 2.46 & $1.83,3.32$ & 1084 & 12.7 & 1.6 & 5.08 & $3.13,8.25$ \\
\hline$p$-value & & & & $<0.0001$ & & & & & $<0.0001$ & \\
\hline \multicolumn{11}{|l|}{ Bone mineral density** } \\
\hline Very high & 1102 & 12.3 & 1.5 & 1.00 & & 1230 & 7.1 & 1.2 & 1.00 & \\
\hline High & 863 & 11.2 & 1.7 & 0.91 & $0.63,1.30$ & 646 & 5.1 & 1.2 & 0.72 & $0.41,1.27$ \\
\hline Low and very low & 385 & 12.9 & 2.2 & 1.04 & $0.68,1.61$ & 326 & 7.9 & 1.8 & 1.11 & $0.68,1.79$ \\
\hline$p$-value & & & & 0.7912 & & & & & $<0.0001$ & \\
\hline \multicolumn{11}{|l|}{ Menopause } \\
\hline No & - & - & - & - & - & 1946 & 5.1 & 0.7 & 1.00 & \\
\hline Yes & - & - & - & - & - & 453 & 12.7 & 2.4 & 2.49 & $1.63,3.81$ \\
\hline$p$-value & & & & & & & & & $<0.0001$ & \\
\hline \multicolumn{11}{|l|}{ Cotinine level } \\
\hline$<1.53$ & 1321 & 5.9 & 0.9 & 1.00 & & 1600 & 3.0 & 0.6 & 1.00 & \\
\hline $1.53-63.39$ & 300 & 11.4 & 2.7 & 1.92 & $1.14,3.23$ & 235 & 11.3 & 3.0 & 3.79 & $2.03,7.09$ \\
\hline $63.40-202.39$ & 285 & 19.4 & 3.2 & 3.27 & $2.05,5.21$ & 177 & 7.7 & 3.2 & 2.58 & $1.07,6.22$ \\
\hline $202.40-305.89$ & 247 & 20.8 & 4.1 & 3.50 & $2.03,6.04$ & 138 & 15.5 & 3.9 & 5.18 & $2.46,10.90$ \\
\hline$>305.89$ & 297 & 25.9 & 3.9 & 4.36 & $2.74,6.95$ & 201 & 18.2 & 4.4 & 6.11 & $3.14,11.90$ \\
\hline$p$-value & & & & $<0.0001$ & & & & & $<0.0001$ & \\
\hline \multicolumn{11}{|l|}{ Smoking status } \\
\hline Never & 888 & 4.1 & 0.7 & 1.00 & & 1439 & 3.7 & 0.6 & 1.00 & \\
\hline Former & 707 & 10.2 & 1.7 & 2.50 & $1.70,3.66$ & 392 & 4.6 & 1.7 & 1.23 & $0.57,2.67$ \\
\hline Current & 905 & 22.4 & 2.6 & 5.47 & $3.50,8.57$ & 568 & 13.2 & 2.5 & 3.54 & $2.25,5.57$ \\
\hline$p$-value & & & & $<0.0001$ & & & & & $<0.0001$ & \\
\hline \multicolumn{11}{|l|}{ Calcium intake (mg) } \\
\hline$\geq 760$ & 1385 & 9.5 & 0.9 & 1.00 & & 924 & 4.6 & 1.0 & 1.00 & \\
\hline$<760$ & 1114 & 15.7 & 2.0 & 1.66 & $1.24,2.23$ & 1475 & 7.8 & 0.9 & 1.69 & $1.07,2.67$ \\
\hline$p$-value & & & & 0.0011 & & & & & 0.0247 & \\
\hline \multicolumn{11}{|l|}{ Diabetes mellitus } \\
\hline No & 2402 & 11.5 & 1.0 & 1.00 & & 2296 & 5.9 & 0.7 & 1.00 & \\
\hline Yes & 98 & 22.8 & 6.2 & 1.98 & $1.13,3.48$ & 103 & 25.3 & 6.2 & 4.31 & $2.64,7.05$ \\
\hline$p$-value & & & & 0.0182 & & & & & $<0.0001$ & \\
\hline \multicolumn{11}{|l|}{ Lead blood level $(\mu \mathrm{g} / \mathrm{dL})$} \\
\hline$<3$ & 773 & 5.5 & 1.1 & 1.00 & & 1713 & 4.1 & 0.7 & 1.00 & \\
\hline $3-7$ & 1268 & 13.5 & 1.4 & 2.45 & $1.53,3.93$ & 596 & 11.5 & 2.0 & 2.76 & $1.67,4.56$ \\
\hline$>7$ & 459 & 25.6 & 3.1 & 4.64 & $2.91,7.40$ & 90 & 39.5 & 10.5 & 9.54 & $5.24,17.34$ \\
\hline$p$-value & & & & $<0.0001$ & & & & & $<0.0001$ & \\
\hline
\end{tabular}

*The number of individuals may very from variable to variable because of missing values of covariates.

†Weighted percentage.

$\ddagger$ Standard error.

- Prevalence ratio.

$\$ 95 \%$ confidence limit.

${ }_{* * *}^{*}$ Levels of bone mineral density (BMD) were calculated separately for men and women, based on the standard deviation of the distribution of bone mineral density for 20-29 yr-old non-Hispanic whites. Very low level of BMD (osteoporosis) refers to $<2.5$ standard deviations from the mean; low level of BMD (osteopenia) refers to scores from 1 to 2.5 standard deviations; high levels refers to 1 to lower than the mean; and very high levels refers to scores above the mean. 
women (prevalence ratio $=3.88,95 \%$ CI: $1.71,8.77)$. However, this difference may be explained by the different distribution of lead exposure between the two groups, which was higher among men. While the majority of women were categorized as having a lead blood level of $<3 \mu \mathrm{g} / \mathrm{dL}$, the majority of men were exposed to higher levels (3-7 $\mu \mathrm{g} / \mathrm{dL})$ (Table 1).

Although significant, the association found in this study needs to be discussed carefully. We began this study with the premise that, in the absence of bias, our results would tend to be an underestimation of the true association, if the association was true. This premise had the argument that current lead blood levels occur partially from recent exposure to lead and partially from accumulated lead in bones, resulting in a large variance of lead exposure. As lead blood levels have been declining in the USA, it can be argued that current lead blood levels among Americans would reflect mostly recent exposure because the turnover of lead in bones may take years, or even decades (2). The decline in lead blood levels was significant during the interval between data collection for the NHANES II survey and the NHANES III survey (46), but only $13 \mathrm{yr}$ had elapsed between introduction of the major regulations to control lead in the USA [control of lead in gasoline (1973) and in paint (1977)] to when NHANES III was conducted (47). It is possible that the contribution of lead from bones, as a result of past exposure, was still a valid assumption in the early 1990s, especially for those people previously exposed to high levels of lead. Considering that bone turnover contributes partially to current lead blood levels, we controlled for factors that can momentarily increase the delivery of lead into the bloodstream, such as menopause and osteopenia/osteoporosis, as well as recent exposure to lead, such as cotinine levels and living in old houses. Moreover, we excluded woman who were pregnant and those who were breast-feeding. If the current levels of lead actually do not reflect past lead exposure, there are two possible interpretations for the association found. As in any cross-sectional study, the current level of one factor can be considered as a surrogate of past exposure. Another possibility is that the lead blood levels reflect an unappreciated variable or residual confounder, in particular something derived from socio-economic level and smoking. Lead exposure and periodontitis are known to be associated with socio-economic status and lifestyle (48). The standard measurements of socio-economic status (income levels and education) have been questioned as valid measurements of the social environment and social class (49). It is possible that with the decline of environmental lead in the USA, lead blood levels has become a better marker for individuals living in unfavorable social environments, and those having deleterious health habits, such as poor nutrition, smoking, or living in old houses in poor neighborhoods. Living in poor and lower-educated neighborhoods per se has been considered as a risk indicator of health effect and also as a predictor of deleterious health behavior, such as a smoking habit and

Table 2. Sequential analysis showing the effect of confounders on the prevalence ratio (PR) for periodontitis $(\geq 10 \%$ of mesial sites with attachment loss $\geq 4 \mathrm{~mm})$ among men $(\mathrm{n}=$ $2500)$ and women $(\mathrm{n}=2399)$ of the $30-55 \mathrm{yr}$ US population [data were obtained from the Third National Health and Nutrition Examination Survey (NHANES III, 1988-94)]

\begin{tabular}{|c|c|c|c|c|c|}
\hline \multirow[b]{2}{*}{ Variables } & \multirow{2}{*}{$\begin{array}{l}\text { Lead blood } \\
\text { level }(\mu \mathrm{g} / \mathrm{dL})\end{array}$} & \multicolumn{2}{|l|}{ Men } & \multicolumn{2}{|l|}{ Women } \\
\hline & & PR-adj. $\dagger$ & $95 \% \mathrm{CI}+$ & PR-adj. & $95 \% \mathrm{CI}$ \\
\hline \multirow[t]{3}{*}{ Crude analysis } & $<3$ & 1.00 & & 1.00 & \\
\hline & $3-7$ & 2.45 & $1.53,3.93$ & 2.76 & $1.67,4.56$ \\
\hline & $>7$ & 4.69 & $2.91,7.40$ & 9.53 & $5.24,17.34$ \\
\hline \multirow[t]{3}{*}{ Age + examiner } & $<3$ & 1.00 & & 1.00 & \\
\hline & $3-7$ & 2.26 & $1.43,3.60$ & 2.46 & $1.46,4.16$ \\
\hline & $>7$ & 3.91 & $2.50,6.13$ & 7.64 & $4.59,12.73$ \\
\hline+ NHANES phase + region + & $<3$ & 1.00 & & 1.00 & \\
\hline house + number of teeth lost + & $3-7$ & 1.68 & $1.08,2.61$ & 1.77 & $0.98,3.19$ \\
\hline menopause (only for women)* & $>7$ & 2.73 & $1.72,4.33$ & 7.02 & $4.26,11.56$ \\
\hline \multirow[t]{3}{*}{+ Povert ratio* } & $<3$ & 1.00 & & 1.00 & \\
\hline & $3-7$ & 1.68 & $1.05,2.69$ & 1.52 & $0.77,3.01$ \\
\hline & $>7$ & 2.58 & $1.63,4.11$ & 5.01 & $2.76,9.07$ \\
\hline \multirow[t]{3}{*}{+ Education* } & $<3$ & 1.00 & & 1.00 & \\
\hline & $3-7$ & 1.65 & $1.04,2.63$ & 1.57 & $0.79,3.12$ \\
\hline & $>7$ & 2.22 & $1.32,3.73$ & 4.68 & $2.49,8.78$ \\
\hline \multirow{3}{*}{+ Race/ethnicity* } & $<3$ & 1.00 & & 1.00 & \\
\hline & $3-7$ & 1.63 & $1.02,2.61$ & 1.54 & $0.77,3.06$ \\
\hline & $>7$ & 2.16 & $1.28,3.66$ & 4.54 & $2.50,8.25$ \\
\hline \multirow[t]{3}{*}{+ Cotinine* } & $<3$ & 1.00 & & 1.00 & \\
\hline & $3-7$ & 1.44 & $0.89,2.34$ & 1.14 & $0.58,2.23$ \\
\hline & $>7$ & 1.74 & $1.02,2.95$ & 3.74 & $1.85,7.55$ \\
\hline \multirow[t]{3}{*}{+ Smoking status* } & $<3$ & 1.00 & & 1.00 & \\
\hline & $3-7$ & 1,44 & $0.88,2.30$ & 1.12 & $0.56,2.23$ \\
\hline & $>7$ & 1.70 & $1.01,2.84$ & 3.73 & $1.83,7.63$ \\
\hline \multirow[t]{3}{*}{+ Diabetes* } & $<3$ & 1.00 & & 1.00 & \\
\hline & $3-7$ & 1.42 & $0.88,2.31$ & 1.15 & $0.58,2.26$ \\
\hline & $>7$ & 1.72 & $1.02,2.90$ & 3.80 & $1.87,7.73$ \\
\hline \multirow[t]{3}{*}{+ Calcium intake* } & $<3$ & 1.00 & & 1.00 & \\
\hline & $3-7$ & 1.38 & $0.85,2.23$ & 1.11 & $0.56,2.22$ \\
\hline & $>7$ & 1.68 & $1.01,2.80$ & 3.75 & $1.84,7.65$ \\
\hline \multirow[t]{3}{*}{+ Dental visit* } & $<3$ & 1.00 & & 1.00 & \\
\hline & $3-7$ & 1.42 & $0.88,2.30$ & 1.10 & $0.53,2.26$ \\
\hline & $>7$ & 1.71 & $1.01,2.87$ & 3.50 & $1.57,7.81$ \\
\hline \multirow[t]{3}{*}{ + Osteoporosis* } & $<3$ & 1.00 & & 1.00 & \\
\hline & $3-7$ & 1.37 & $0.84,2.23$ & 1.15 & $0.55,2.37$ \\
\hline & $>7$ & 1.70 & $1.02,2.85$ & 3.80 & $1.66,8.73$ \\
\hline
\end{tabular}

*This variable is added to the model containing the all the variables in previous row. $\uparrow$ Adjusted prevalence ratio, except for the first row, which shows the crude prevalence ratio. $\$ 95 \%$ confidence limit. 
Table 3. Interaction between smoking status and lead blood levels, with and without cotinine, in the model

\begin{tabular}{|c|c|c|c|c|c|}
\hline \multirow[b]{2}{*}{ Variables } & \multirow{2}{*}{$\begin{array}{l}\text { Lead blood } \\
\text { level }(\mu \mathrm{g} / \mathrm{dL})\end{array}$} & \multicolumn{2}{|c|}{ Men } & \multicolumn{2}{|c|}{ Women } \\
\hline & & PR-adj. $\uparrow$ & $95 \% \mathrm{CI} \dagger$ & PR & $95 \% \mathrm{CI}$ \\
\hline \multicolumn{6}{|c|}{$\frac{\text { Interaction with cotinine }}{\text { level in the model }}$} \\
\hline \multirow[t]{3}{*}{ Never smokers } & $<3$ & 1.00 & & 1.00 & \\
\hline & $3-7$ & 1.19 & $0.51,2.77$ & 1.01 & $0.37,2.81$ \\
\hline & $>7$ & 1.25 & $0.43,3.61$ & 2.59 & $0.85,7.90$ \\
\hline \multirow{3}{*}{ Past smokers } & $<3$ & 1.44 & $0.59,3.53$ & 0.49 & $0.10,2.33$ \\
\hline & $3-7$ & 1.83 & $0.77,4.36$ & 1.67 & $0.55,5.01$ \\
\hline & $>7$ & 3.17 & $1.24,8.09$ & 9.04 & $2.41,33.94$ \\
\hline \multirow[t]{3}{*}{ Current smokers } & $<3$ & 1.79 & $0.70,4.56$ & 0.69 & $0.18,2.57$ \\
\hline & $3-7$ & 2.72 & $1.08,6.83$ & 0.71 & $0.14,3.52$ \\
\hline & $>7$ & 3.07 & $1.22,7.71$ & 1.79 & $0.38,8.41$ \\
\hline$p$-value* & & & 0.8253 & & 0.3514 \\
\hline \multicolumn{6}{|c|}{$\begin{array}{l}\text { Interaction without cotinine } \\
\text { level in the model }\end{array}$} \\
\hline \multirow[t]{3}{*}{ Never smokers } & $<3$ & 1.00 & & 1.00 & \\
\hline & $3-7$ & 1.25 & $0.55,2.83$ & 1.04 & $0.40,2.69$ \\
\hline & $>7$ & 1.36 & $0.48,3.88$ & 2.49 & $0.70,8.84$ \\
\hline \multirow[t]{3}{*}{ Past smokers } & $<3$ & 1.69 & $0.71,4.03$ & 0.51 & $0.09,3.01$ \\
\hline & $3-7$ & 1.92 & $0.83,4.44$ & 2.16 & $0.83,5.61$ \\
\hline & $>7$ & 3.27 & $1.29,8.29$ & 8.28 & $2.16,31.75$ \\
\hline \multirow[t]{3}{*}{ Current smokers } & $<3$ & 2.29 & $0.94,5.61$ & 2.65 & $1.28,5.46$ \\
\hline & $3-7$ & 3.57 & $1.61,7.95$ & 3.02 & $1.22,7.51$ \\
\hline & $>7$ & 4.10 & $1.77,9.51$ & 7.18 & $3.12,16.55$ \\
\hline$p$-value* & & & 0.8360 & & 0.5243 \\
\hline
\end{tabular}

* $p$-value for the interaction between smoking status and lead blood level.

$\dagger$ Adjusted prevalence ratio.

$\$ 95 \%$ confidence limit.

lower physical activity (50). It is possible that oral hygiene and willingness to access dental treatment, which is associated with periodontitis (51), may also be predicted by the neighborhood environment. Moreover, there is some evidence that negative life events and psychosocial stress may be associated with periodontitis (52). Another possibility is that sustained hardship for long periods of time may also characterize individuals living in the deprived and contaminated areas. Elreedy et al. (1), reported that even after controlling for traditional individual indicators of socio-economic status, residence in a more deprived geographical area was a modifier of cumulative lead exposure in bone. Although the mechanism is not well understood, the contextual effect of living in a deprived area has been reported as an independent risk factor for several diseases (53), including dental caries (54). It is possible that contamination with lead and other toxicants may, in part, explain this contextual effect. There is also some evidence that lead is highly absorbed in individuals with poor nutrition, and who have low calcium and vitamin D intake, conditions that are more likely to be observed in poor neighborhoods $(1,55,56)$. We tested interaction between calcium intake and iron intake in our study (data not shown) but neither calcium nor iron was an effect modifier. However, the lack of evidence of interaction in a cross-sectional study does not rule out the possibility of a past interaction. Therefore, we cannot rule out that the association found in this study between lead blood levels and periodontitis might be a residual confounder of socio-economic status, which was represented in this study only by poverty level and education. However, some other variables that could, to a certain extent, reflect other characteristics of social position were also used in this study, such as frequency of dental visity and age of the house. Nevertheless, it is is not known by how much these variables actually reduced the influence of residual confounders.

Residual confounder from smoking is another potential threat to the validity of any study of risk factors for periodontitis (57). Associations of periodontitis with systemic diseases have been attributed mostly to residual confounding from smoking (57).

Despite theoretical explanations for the association found in this study, it is important to point out that the association between lead blood levels and attachment loss was moderate and very stable, independently of confounders.

A major limitation of this study is its design, facing the constant decline of lead exposure in the USA and its unequal decline associated with socioeconomic position. Moreover, the low levels of lead, and the consequently relatively small sample size of people with high exposure, preclude us from testing interactions that could be important in understanding the association. None of the interactions tested were statistically significant.

In spite of some weaknesses, the strength of this study is that NHANES III is a complex random sample representative of the US population, and thus selection bias common to occupational studies is not expected to be responsible for our results.

By contrast with a recent analysis of NHANES III (35), in which attachment loss was evaluated as a possible source of lead delivered into the bloodstream, we failed to observe an interaction between smoking and lead blood levels. One possible reason is that we excluded individuals over 56 yr old to avoid a survivorship influence. In spite of better oral health, the inclusion of individuals older than $55 \mathrm{yr}$ old increases the proportion of individuals with possible confounders such as osteopenia, osteoporosis, and menopause. These conditions are associated with increased bone turnover, resulting in an increase of lead blood levels $(36,43)$, and are also associated with periodontitis. In that study there were no adjustments for such conditions, or even adjustment for the number of teeth present in the mouth (57). 
This study showed a positive statistically significant association between $\mathrm{PbB}$ and periodontitis after adjusting for major known risk factors. In spite of relatively low levels of exposure to lead among the US population, the persistence of lead contamination among areas of underprivileged segments of society, as well as a higher prevalence of periodontitis among the poorest, further studies are necessary to confirm this association. Studies using cumulative measures of lead, as well as studies using populations or occupational groups exposed to high levels of lead, may give us a more complete picture of the statistical association found in this study.

\section{References}

1. Elreedy S, Krieger N, Ryan P, Sparrow D, Weiss ST, Hu H. Relations between individual and neighborhood-based measures of socioeconomic position and bone lead concentrations among communityexposed men. Am J Epidemiol 1999;150: 129-141.

2. Pirkle JL, Brody DJ, Gunter EW et al. The decline in the blood lead levels in the United States. The National health and Nutritional Examination Surveys (NHANES). J Am Med Assoc 1994;272:284-291.

3. Payton M, Hu H, Sparrow D, Weiss ST. Low-level lead exposure and renal function in the Normative Aging Study. Am J Epidemiol 1994;140:821-829.

4. Cheng Y, Schwartz J, Sparrow D, Aro A, Weiss ST, Hu H. Bone lead and blood lead levels in relation to baseline blood pressure and the prospective development of hypertension. Am $J$ Epidemiol 2001;153:164-171.

5. Pounds JG, Long GJ, Rosen JF. Cellular and molecular toxicity of lead in bone. Environ Health Perspect 1991;91:17-32.

6. Silbergeld EK, Sauk J, Sommerman M et al. Lead in bone: storage site, exposure source, target organ. Neurotoxicology 1993;14:225-236.

7. Pinkerton LE, Biagini RE, Ward EM et al. Immunologic findings among leadexposed workers. Am J Ind Med 1998;33:400-408.

8. Pineda-Zavaleta AP, Garcia-Vargas G, Borja-Aburto VH et al. Nitric oxide and superoxide anion production in monocytes from children exposed to arsenic and lead in region Lagunera, Mexico. Toxicol Appl Pharmacol 2004;198:283-290.

9. Offenbacher S. Periodontal diseases: pathogenesis. Ann Periodontol 1996;1:821878.
10. Mundy GR, Guise TA. Hormonal control of calcium homeostasis. Clin Chem 1999;45:1347-1352.

11. Sauk JJ, Smith T, Silbergeld EK, Fowler B, Sommerman M. Lead inhibits secretion of osteonectin/SPARC without significantly altering collagen or Hsp47 production on osteoblast like ROS 17/2.8 cells. Toxicol Appl Pharmacol 1992;116:240-247.

12. Goldberg RL, Kaplan SR, Fuller GC. Effect of heavy metals on human rheumatoid synovial cell proliferation and collagen synthesis. Biochem Pharmacol 1983;32:2763-2766.

13. Dowd TL, Rosen JF, Gundberg CM, Gupta RK. The displacement of calcium from osteocalcin at submicromolar concentrations of free lead. Biochem Biophys Acta 1994;1226:131-137.

14. Miyahara T, Komiyama H, Miyanishi A et al. Stimulative effects of lead on bone resorption in organ culture. Toxicology 1995;97:191-197.

15. Lee JJ, Battles AH. Lead toxicity via arachidonate signal transduction to growth responses in the splenic macrophage. Environ Res 1994;67:209-219.

16. Koo W, Succop PA, Bornschein RL et al. Serum vitamin $\mathrm{D}$ metabolites and bone mineralization in young children with chronic low to moderate lead exposure. Pediatrics 1991;87:680-687.

17. Kim RHH, Rotnitzzky A, Bellinger DC, Needleman HL. A longitudinal study of chronic lead exposure and physical growth in Boston children. Environ Health Perspect 1995;103:952-957.

18. Schwartz J, Angle C, Pitcher H. Relationship between childhood blood lead levels and stature. Pediatrics 1986;77:281288.

19. Gruber HH, Gonickm HC, Khalil-Manesh $\mathrm{F}$ et al. Ostepenia induced by long term, low- and high-level exposure of the adult rat to lead. Miner Electrolyte Metab 1997;23:65-73.

20. Gruber HH, Ding Y, Stasky AA et al. Adequate dietary calcium mitigates osteopenia induced by chronic lead exposure in adult rats. Miner Electrolyte Metab 1999;25:143-146.

21. Hemphill F, Kaeberle MWB. Lead suppression of mouse resistance to Salmonella typhimurium. Science 1971;172:1031-1032.

22. McCabe MJ Jr, Lawrence DA. Lead, a major environmental pollutant, is immunomodulatory by its differential effects on CD4 + T cell subsets. Toxicol Appl Pharmacol 1991;111:13-23.

23. Dentener MA, Greve JW, Maessen JG, Buurman WA. Role of tummor necrosis factor in the enhanced sensitivity of mice to endotoxin after exposure to lead. Immunopharmacol Immunotoxicol 1989;11:321-334.
24. Kishikawa H, Song R, Lawrence DA. Interleukin-12 promotes enhanced resistance to Listeria monocytogenes infection of lead-exposed mice. Toxicol Appl Pharmacol 1997;147:180-189.

25. Fishchein A, Tsang P, Luo JC, Roboz JP, Jiang JD, Bekesi JG. Phenotypic aberrations of $\mathrm{CD} 3+$ and $\mathrm{CD} 4+$ cells and functional impairments of lymphocytes at low-level occupational exposure to lead. Clin Immunol Immunopathol 1993;66:163168.

26. Underger $\mathrm{U}$, Basaran $\mathrm{N}$, Campinar $\mathrm{H}$, Kansu E. Immune alterations in lead-exposed workers. Toxicology 1996;109:167172.

27. Queiroz ML, Almeida M, Gallao MI, Hoehr NF. Defective neutrophil function in workers occupationally exposed to lead. Pharmacol Toxicol 1993;72:73-77.

28. Queiroz ML, Perlingeiro RC, Almeida M, Bincoletto C, Cardoso MP, Daniel DC. Immunoglobulin levels and cellular immune function in lead exposed workers. Immunopharmacol Immunotoxicol 1994;16:115-128.

29. Daniel D, Van Dyke TE. Alterations in phagocyte function and periodontal infection. $J$ Periodontol 1996;67:10701075.

30. Wactawski-Wende J, Grossi SG, Trevisan M, Tezal M, Genco RJ. The role of osteopenia on oral bone loss and periodontal disease. J Periodontol 1996;67:1076-1084.

31. Yamamoto M, Fujihashi K, McGee JR, Van Dyke TE, Kiyono H. Molecular and cellular mechanisms for periodontal diseases: role of Th1 and Th2 type cytokines in induction of mucosal inflammation. J Periodont Res 1997;32:115-119.

32. Carmouche JJ, Puzas JE, Zhang X et al. Lead exposure inhibitis fracture healing and is associated with increased chodrogenesis, delay in cartilage mineralization, and decrease in osteoprogenitor frequency. Environ Health Perspect 2005; 113:749-755.

33. Baranska-Gachowska M, Postek L, Soja J. [The effect of an environment contaminated with lead and cadmium compounds on the condition of teeth in schoolchildren in Zyglin and Pniowiec]. Cza Stomatol 1987;40:158-165.

34. Stawinski K, Szponar E, Orkiszewa M. Diseases of periodontium and oral mucosa in workers exposed to various harmful working environmental factors. Cza Stomatol 1987;40:137-141.

35. Dye BA, Hirsch R, Brody DJ. The relationship between blood lead levels and periodontal bone loss in the United States. Environ Health Perspect 2002;110:9971002.

36. Nash D, Magder LS, Sherwin R, Rubin RJ, Silbergeld EK. Bone density-related predictors of blood lead level among 
peri- and postmenopausal women in the United States. The Third National Health Nutrition Examination Survey, 19881994. Am J Epidemiol 2004;160:901-911.

37. Nishida M, Grossi SG, Dunford RG, Ho AW, Trevisan M, Genco RJ. Calcium and the risk for periodontal disease. J Periodontol 2000;71:1057-1066.

38. National Center for Health Statistics CfDCaP. Analytic and reporting guidelines: The Third National Health and Nutrition Examination Survey, NHANES III (1988-94). Hyattsville, MD: Center for Disease Control and Prevention, 1996.

39. National Health for Statistics. National Health and Nutrition Examination Survey III. Oral Examination Component. Hyattsville, MD: Center for Disease Control and Prevention, 1992.

40. Slade GD, Offenbacher S, Beck JD, Heiss G, Pankow JS. Acute-phase inflammatory response to periodontal disease in US population. J Dent Res 2000;79:49-57.

41. US Department of Health and Human Services (DHSS) National Center for Health Statistics. NHANES III reference manual and reports (CD-ROM). Hyattsville: Center for Disease Control and Prevention, 1997.

42. World Health Organization. Assessment of Fracture Risk and its Applications to Screen for Postmenopausal Osteoporosis. Geneva: World Health Organization, 1994.

43. Nordin BEC, Wishart JM, Clifton PM, McArthur R, Morris HA, O'Loughlin
PD. A longitudinal study of bone-related biochemical changes at the menopause. Clin Endocrinol 2004;61:123-130.

44. Akesson A, Vahter M, Berglund M, Eklof T, Bremme K, Bjellerup P. Bone turnover from early pregnancy to postweaning. Acta Obstet Gynecol Scand 2004;3:10491055.

45. Barros AJ, Hirakata VN. Alternatives for logistic regression in cross-sectional studies: empirical comparison of models that directly estimate the prevalence ratio. BMC Med Res Methodol 2003;20:21.

46. Pirkle JL, Kaufmann RB, Brody DJ, Hickman T, Gunter EW, Paschal DC. Exposure of the US population to lead, 1991-94. Environ Health Perspect 1998; 106:745-750.

47. US. Department of Health \& Human Services PHS AfTSaDR. Toxicological Profile for Lead. Atlanta: Agency for Toxic Substance and Disease Registry, 1999

48. Hu H, Payton M, Korrick S, Sparrow D, Weiss ST, Rotnitzzky A. Determinants of bone and blood lead levels among community-exposed middle-aged to elderly men. The normative aging study. Am J Epidemiol 1996;144:479-459.

49. Krieger N, Williams DR, Moss NE. Measuring social class in US public health research: concepts, methodologies and guidelines. Annu Rev Public Health 1997;18:341-378.

50. Yen IH, Kaplan GA. Neighborhood social environment and risk of death multilevel evidence from Alameda County. Am J Epidemiol 1999;149:898-907.

51. Lang WP, Ronis DL, Farghaly MM. Preventive behaviors as correlates to periodontal health. $J$ Public Health Dent 1995;55:10-17.

52. Locker D, Jacovic A, Payne B. Life circumstances, lifestyles and oral health among older Canadians. Community Dental Health 1997;14:214-220.

53. Rautio N, Adamson J, Heikkinen E, Ebrahim S. Associations of socio-economic position and disability among older woman in Britain and Jyvaskyla, Finland Arch Gerontol Geriatr 2006;42:141-145.

54. Dugmore CR, Rock WP. The effect of socio-economic status and ethnicity on the comparative oral health of Asian and White Caucasian 12-year-old children. Community Dent Health 2005;22:162-169.

55. Cheng Y, Willet WC, Schwartz J. Relation of nutrition to bone lead and blood lead levels in middle-aged to elderly men: the normative aging study. Am $J$ Epidemiol 1998;147:1162-1174.

56. Mahaffey KR. Environment lead toxicity: nutrition as component of intervention. Environ Health Perspect 1990;89:75-78.

57. Spiekerman CF, Hujoel PP, De Roen TA Bias induced by self-reported smoking on periodontitis-systemic disease associations. J Dent Res 2003;82:345-349. 